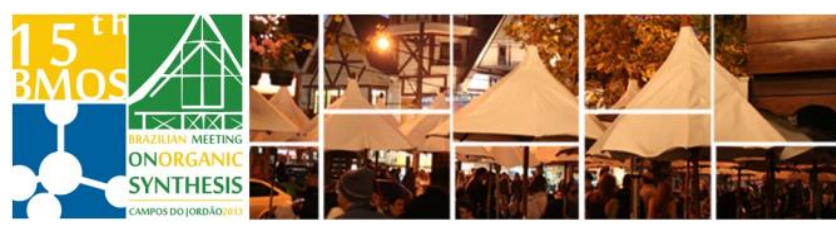

\title{
Asymmetric synthesis of pyranocumarins under greener conditions
}

\author{
Monteiro, J. L.; Torre, A. F.; Paixão M. P.; Corrêa A. G. \\ Federal University of São Carlos UFSCar, SP - Brazil. \\ *ju.lammoglia@gmail.com
}

Keywords: Pyranocumarins, asymmetric synthesis, Alzheimer's disease, organocatalysis

\section{INTRODUCTION}

Coumarins, in particular pyranocoumarins, are known as potent inhibitors of acetylcholinesterase enzyme primarily responsible for neurodegenerative disorders such as Alzheimer's disease. ${ }^{1}$ Rueping et al. reported the asymmetric synthesis of pyranocoumarins using the Jørgensen-Hayashi organocatalyst $(20 \mathrm{~mol} \%)$ in dichloromethane at 10 ${ }^{\circ} \mathrm{C}$ for 48-96 h. ${ }^{2}$ The study and development of new methodologies for faster, greener, and more selective synthesis of bioactive compounds is of great interest. This study aims to explore the asymmetric synthesis of pyranocoumarins under eco-friendly reaction conditions.

\section{RESULTS AND DISCUSSION}

Initially, we have study the reaction of $\alpha, \beta$ unsaturated aldehydes with 4-hydroxycoumarin (1), which was obtained from o-hydroxyacetophenone and diethyl carbonate in $83 \%$ yield. ${ }^{3}$ The synthesis of pyranocoumarins started with the reaction of 4hydroxycoumarin (1) with trans-2-decenal (2) using the organocatalysts newly developed by our research group, that allow the use of alternative solvents ${ }^{4}$ (Table 1).

Table 1. Asymmetric organocatalytic synthesis of pyranocumarins - scope of the organocatalysts ${ }^{a}$

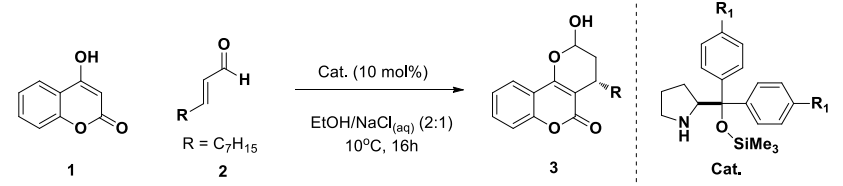

\begin{tabular}{|c|c|c|c|}
\hline Entry & Catalyst $^{\left(R_{1}\right)}$ & Yield (\%) $^{\boldsymbol{b}}$ & $\boldsymbol{e e}^{\boldsymbol{c}}$ \\
\hline $\mathbf{1}$ & $\mathrm{SC}_{6} \mathrm{H}_{13}$ & 90 & 83 \\
\hline $\mathbf{2}^{\boldsymbol{d}}$ & $\mathbf{S C}_{6} \mathrm{H}_{13}$ & $\mathbf{9 1}$ & $\mathbf{8 7}$ \\
\hline $\mathbf{3}$ & $\mathrm{SC}_{2} \mathrm{H}_{5}$ & 93 & 81 \\
\hline $\mathbf{4}$ & $\mathrm{SC}_{12} \mathrm{H}_{25}$ & 89 & 85 \\
\hline $\mathbf{5}$ & $\mathrm{OC}_{6} \mathrm{H}_{13}$ & 83 & 81 \\
\hline
\end{tabular}

a Reactions were performed with 4-hydroxycoumarin (1) (1.0 equiv.), trans- 2-decenal (2) (1.3 equiv.), $10 \mathrm{~mol} \%$ of the catalyst and $10 \mathrm{~mol} \%$ of co-catalyst benzoic acid. ${ }^{b}$ Yields after isolation by flash chromatography. ${ }^{c}$ Determined by chiral-phase HPLC. ${ }^{d}$ Reaction with 20 mol\% of catalyst.

Having established the optimal catalyst for the reaction (Entry 2), we explored the influence of the solvent, temperature and presence of the co-catalyst (Table 2).

Table 2.Asymmetric organocatalytic pyranocumarins - scope of the solvent and temperature ${ }^{a}$
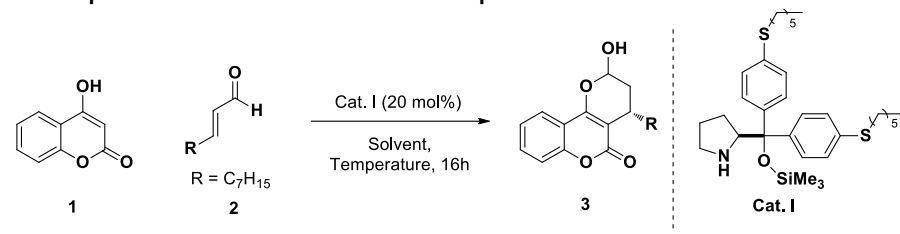

\begin{tabular}{|c|c|c|c|}
\hline Entry & Solvent & Yield (\%) $^{b}$ & $e e^{c}$ \\
\hline 1 & $\mathrm{EtOH} / \mathrm{NaCl}_{(\mathrm{aq})}(2: 1)$ & 91 & 87 \\
\hline 2 & $\mathrm{EtOH}$ & 74 & 86 \\
\hline 3 & $\mathrm{NaCl}_{(\mathrm{aq})} / \mathrm{EtOH}(3: 1)$ & 40 & 84 \\
\hline 4 & $\mathrm{H}_{2} \mathrm{O} / \mathrm{EtOH}(3: 1)$ & 53 & 83 \\
\hline 5 & Glycerol/EtOH (3:1) & 68 & 82 \\
\hline $6^{d}$ & $\mathrm{EtOH} / \mathrm{NaCl}_{(\mathrm{aq})}(3: 1)$ & 74 & 89 \\
\hline $7^{e}$ & $\mathrm{EtOH} / \mathrm{NaCl}_{(\mathrm{aq})}(3: 1)$ & 85 & 88 \\
\hline $8^{f}$ & $\mathrm{EtOH} / \mathrm{NaCl}_{(\mathrm{aq})}(3: 1)$ & 81 & 88 \\
\hline $9^{d e}$ & $\mathrm{EtOH} / \mathrm{NaCl}_{(\mathrm{aq})}(2: 1)$ & 87 & 91 \\
\hline
\end{tabular}

${ }^{a}$ Reactions were performed with 4-hydroxycoumarin (1) (1.0 equiv.), trans- 2-decenal (2) (1.3 equiv.), $20 \mathrm{~mol} \%$ of the catalyst, $10 \mathrm{~mol} \%$ of co-catalyst benzoic acid and at $10^{\circ} \mathrm{C} .{ }^{b}$ Yields after isolation by flash chromatography. ${ }^{c}$ Determined by chiral-phase HPLC. ${ }^{d}$ Reaction without co-catalyst. ${ }^{e}$ Reaction was performed at $-10^{\circ} \mathrm{C} .{ }^{f}$ Reaction was performed at $20^{\circ} \mathrm{C}$.

The best reaction conditions for the formation of pyranocoumarin 3 are described in Entry 9.

\section{CONCLUSION}

The methodology tested was effective in the synthesis of pyranocoumarins using green solvents in short reaction times. The study of the scope of the reaction by using aliphatic and aromatic $\alpha, \beta-$ unsaturated aldehydes is under investigation. The pyranocoumarins will be evaluated against acetylcholinesterase enzyme.

\section{ACKNOWLEDGEMENTS}

FAPESP, CNPq, CAPES.

\section{REFERENCES}

${ }^{1}$ Silva, J. I.; Moraes, M. C.; Vieira, L. C. C.; Correa, A. G.; Cass, Q. B.; Cardoso, C. L. J. Pharmaceut. Biomed. Anal. 2013, 73, 44. Han, J.; Lee, S.; Kim, H. M.; Shin, B. Bull. Korean Chem. Soc. 2008, 29, 1572.

${ }^{2}$ Rueping, M.; Merino, E.; Sugoino, E.; Adv. Synth. Catal. 2008, 350, 2127.

${ }^{3}$ Yang, G.; Wu, J.; Zhan, C.; Huang, X.; Zhu, X.; Wang, L.; Zhao, P. J.Am. Chem. Soc. 2010, 132, 185.

${ }^{4}$ Deobald, A. M.; Corrêa, A. G; Rivera, D. G; Paixão, M. P. Org. Biomol.

Chem. 2012, 10, 7681 . 